\title{
Characteristics of the Criminal Procedure Model and the Proceedings, Several Comparative Research
}

\author{
PhD. Nguyen Ngoc Kien \\ Faculty of Criminal Law \\ University of Law \\ Hue University, Viet Nam.
}

\begin{abstract}
Summary:
The article (i) clarifies the origin, content and characteristics of the criminal procedural ${ }^{l}$ model in the world, together with the contrast between the interrogation procedure model and the litigious procedural mode; (ii) clarifies the relationship between procedural models and court characteristics and characteristics of litigation procedures; (iii) states the need to study the comparison between the procedure of litigation at the criminal trial in the United States, Japan and Vietnam and provide in-depth comments, as well as draw assessments and conclusions about litigation procedures and related matters in relation to the used procedural system.
\end{abstract}

Key words: Criminal procedural model, litigation, Court.

\section{Identify and characterize the types of criminal procedure models in the world}

The interrogative CP model originated from the ancient Roman Law, formed in the 6th century BC by Emperor Justinian; later perfected by French and German lawyers. The interrogation procedure with the advantage of being controlled by the state and avoiding the abolition of criminals was the most effective, but the disadvantage was the limitation of vulnerable human rights, such as abuse of power, abuse of measures enforcement of CP. The author Craig M. Bradley - Indiana University Law Professor, USA stated in the "Criminal Procedure A Worldwide Study", that: the continental model has a distinct advantage, much more effective than the common law method. There the Judges consider using state resources to discover all the evidence, wherever it can, to seek for the truth ${ }^{2}$.

In the development history of CP law, the first procedural model appeared to be litigation. This model was applied in ancient Greece, then introduced into Rome with the name "continuous inquiry procedure" (Procédure des questions perpétuelle). Procedures for "continuous questioning" or can also be called litigation. Because at that time people conceived that crime was an individual category, therefore the State would not intervene. The criminal case came from the victim or the person involved initiating a lawsuit before the court to judge. The petitioner must collected evidence for his / her accusation, the defendant had the right to give arguments and evidence to counter. The Court played the role of arbitrator, but did not participate in the questioning or investigation and collection of evidence $\mathrm{e}^{3}$. The characteristic elements of the aforementioned litigation system were very primitive while the society had not yet developed; the concept of the impact of criminal acts only stopped at the individual perspective but had not extended to the whole society. In England, the CP model of litigation appeared around the 10th to 13th centuries, on the basis of two parties denouncing before the Court, and was recognized by the law for equality for both parties by the Court acting as the referee observing and judging ${ }^{4}$. After that, the litigation procedure was developed in the British colonies of the United States, Canada, Australia ... and existed to this day.

The CP model argued that the truth of the case would be opened through the open and equal debate of the interested parties at the trial. These are the "struggles" in arguing and giving out evidence from the accused and defending, therefore the trials take place democratically and vividly. There is a restriction of state intervention in the legitimate interests of citizens, by regulating many rights for the accused to motivate them to protect themselves, rather than waiting for judicial officers. That shows the proportionality and equality in litigation, as well as guaranteed human rights.

\footnotetext{
${ }^{1}$ The following is an abbreviation of the term "criminal procedure" as "CP".

${ }^{2}$ Craig M. Bradley, Criminal Procedure A Worldwide Study, (Durham- North Carolina: Carolina Academic Press, 2007), source http://cap-press.com/books/isbn/9781594602443/Criminal-Procedure-Second-Edition

3"Vietnam Criminal Procedure Model Project" issued by the Supreme People's Procuracy, Vietnam in 2012 in Hanoi, p.26

${ }^{4}$ Source: K. Ph. Gusenco, Criminal Procedure Code Textbook, (Publishing House of Zer-Californian, Moscow, 2000), p.1920.
} 
However, litigation model has diclosured its limitation, that is the state must spend more cost of litigation due to the establishment of a system of monitoring mechanisms to control errors from procedural activities and due to the lengthen duration of the trial in the litigation system. In addition, the State also faces difficulties in controlling crime. Crime may be dropped. For reasons: firstly, the State wishes to seek for the truth at the trial, not the truth expected at the investigation stage. From such a point of view, the State has stipulated the collection of evidence and the record of cases equally for the accusers and offenders. Although this may not be professional, leading to evidence can be scattered, missed and neglected offenses. Secondly, because the State values basic human rights, such as the right to privacy, the personal freedom of the offender, etc. Therefore, the establishment of some proceedings is limited, making it difficult for judicial officers. Most obvious difficulty is the impact on the collection of evidence and documents.

In the process of applying the procedural model in each country in the world, there are different characteristics and interference, learning from each other very soon. Research results by author K.Ph. Gusenco ${ }^{5}$ - with a view of the legal history, when it comes to the assumption that each CP model has a mutual influence and acquirements, has appeared since 1808, with the first legal basis was the French Code of the Criminal Procedure in 1808. There, it continued to show the characteristics of the interrogation CP model that France has chosen (namely the Institutional Investigation Institution in the Court and the interrogation procedures at the trial). But it has established a new trial of Jurors, and is more important than the right to defend at trial to ensure equality and democracy when litigation; establish some basic rights for the accused, such as the right to have a lawyer next to them when they are suspected of committing a crime or being arrested, the right to petition and make requests; ensure the independence of the Judge; Although the Inquiry of the Court has a great power, it is still dominated by the Prosecutor Institute.

Author K.Ph. Gusenco also said that countries in continental Europe such as Germany, Austria, Belgium, Denmark, Russia and the Netherlands had the influence of the French CP Code in 1808. Those were the countries that apply the $\mathrm{CP}$ model interweaving elements of interrogation systems and litigation systems to take advantage of them. Meanwhile in Germany, in 1848 they set up a trial with a juror (the judges were not professional, not paid but they had legal knowledge and desire to devote to the law). In Russia, in 1864, a large judicial reform took place. In the CP model, there was a receptive to the characteristics of the CP model of France 6 . With the most prominent feature in the law of the France $\mathrm{CP}$ at that time was the trial juror regime. It had a profound effect on many countries in Europe that were mentioned above. By 1917 the Soviet government established, despite continuing to develop its procedural model, but according to the socialist nature of the proletarian government (there are many characteristics that were no longer the same as the CP model of France and Germany).

Italy was a good example of a procedural paradigm shift. In 1989, Italy transformed its traditional CP model into a litigation CP model, with the purpose of protecting human rights better. But after only two years of implementation there were many problems, especially cases involving the Mafia, when litigating at trial, for fear of retaliation, most of the witnesses' testimonies contradicted completely with their initial testimonies written during the pre-trial period. That made it difficult to prove the truth of the case. Therefore, Italy has returned to the interrogation model as before and until now the law, as well as the precedents of this country's Court of breaking case, often had to rectify it to reestablish $^{7}$. The new Italian Criminal Code of 1989 (Nuovo codice di procedura penale) (English name: the New Criminal Procedure Code) is a combination of strict adversarial and inquiry methods. As assessed by author Julia Grace Mirabella $^{8}$, that combination has helped the Italian legal background to be a civil law legislation, approaching the litigation model of the United States. The transformation of Italy's procedural model is a good experience for countries with strong judicial reforms like Vietnam. The above points are further clarified in the following tables:

\footnotetext{
${ }^{5}$ Source: K. Ph. Gusenco, Criminal Procedure Code Textbook, (Publishing House of Zer-Californian, Moscow, 2000), p.1920.

${ }^{6}$ Source: K. Ph. Gusenco, Criminal Procedure Code Textbook, (Publishing House of Zer-Californian, Moscow, 2000), p.1920.

7"Vietnam Criminal Procedure Model Project" issued by the Supreme People's Procuracy, Vietnam in 2012 in Hanoi, p.34

${ }^{8}$ Julia Grace Mirabella, "Scales of justice: Assessing Italian criminal procedure through the Amanda Knox trial", (2012), International Law Journal, Boston University, USA, no 30, p. 229- 260.
} 
Table 1. The contrast between the interrogation system and the litigation system

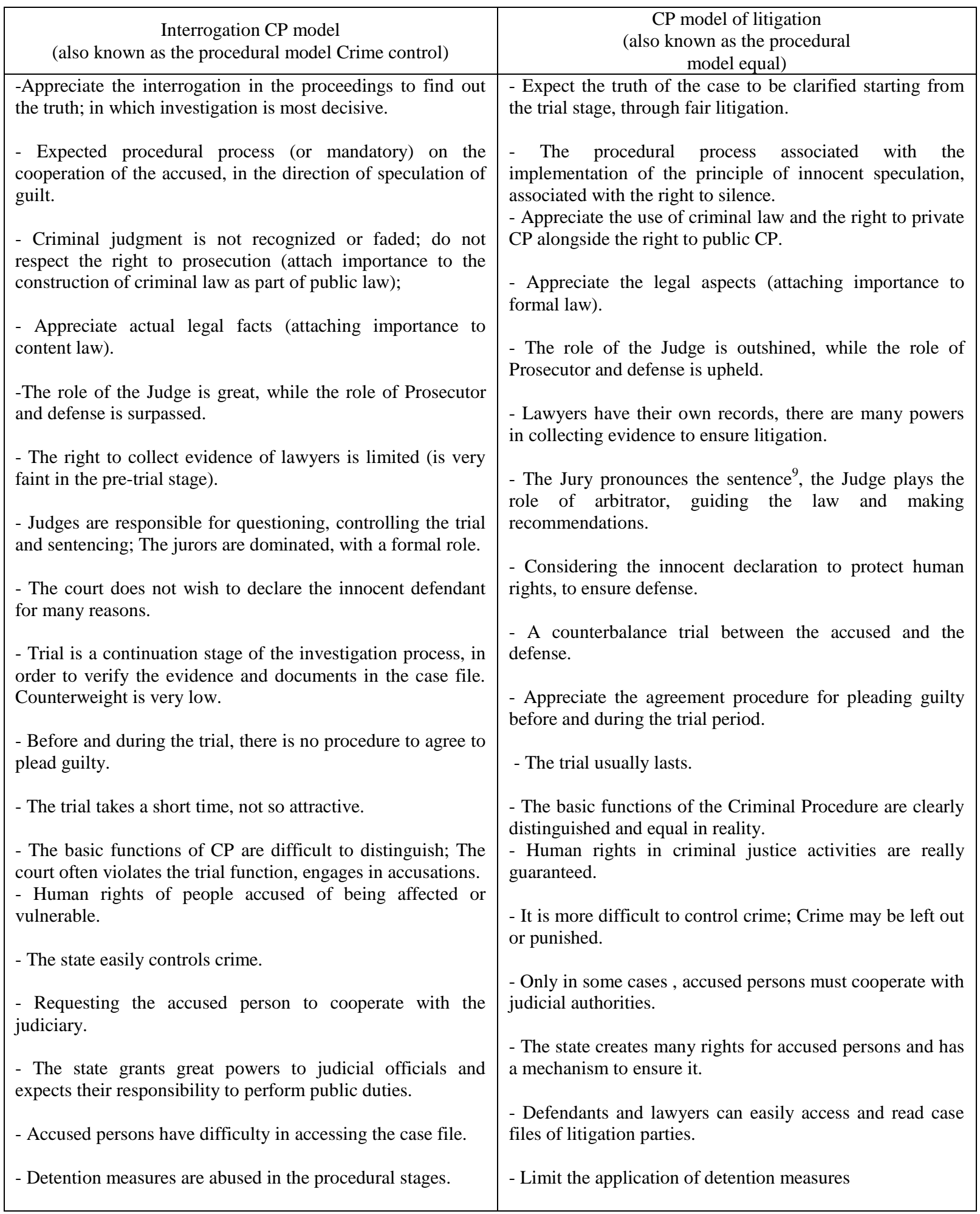

\footnotetext{
${ }^{9}$ In Vietnam, they are called Jurors
} 
Table 2. The contrast of litigation procedures in the internal trial Interrogation $\mathrm{CP}$ model, compared to litigation CP model

\begin{tabular}{|c|c|}
\hline Interrogation CP model & Litigation CP model \\
\hline $\begin{array}{l}\text { - A judge would study the case file for a period of } 2 \text { to } \\
3 \text { months, (called trial preparation) for the trial to be } \\
\text { opened soon. } \\
\text { - Procedure to start the trial (the chairman declares } \\
\text { the trial, checks the identity of the participants in the } \\
\text { proceedings; explains the rights and obligations to the } \\
\text { participants in the procedure ...). } \\
\text { - Prosecutor reads the indictment (may have notice } \\
\text { and explane of the right to the defendant or additional } \\
\text { indictment). } \\
\text { - In the interrogation section, in turn the Judges, } \\
\text { Assessors, Prosecutors and defense counsels } \\
\text { interrogate the accused person, then ask the victim and } \\
\text { other procedural participants (other procedure } \\
\text { participants have the right to request to ask, but must } \\
\text { be agreed by the presiding judge). } \\
\text { - In the debate, the Prosecutor reads the Criminal } \\
\text { Statement, the defense counsel reads the excuse. } \\
\text { Prosecutors and lawyers argue, (the defendant made a } \\
\text { controversial opinion if desired). } \\
\text { - The defendant said the last word. } \\
\text { - Judgment and sentencing (The Trial Panel decides } \\
\text { the sentence level and sentencing) }\end{array}$ & $\begin{array}{l}\text { - Preliminary procedures (before the opening of } \\
\text { the formal trial), (procedures for negotiating } \\
\text { pleasures between lawyers and accused persons, } \\
\text { there may be witnesses of Judges). } \\
\text { - Procedure to start the trial (introduction of the } \\
\text { participants in the litigation session; Judge and } \\
\text { the Jury take an the oath; Judge notifies the } \\
\text { defendant the right to silence at the trial; the } \\
\text { procedure of accused person admit or not admit } \\
\text { the crime...). } \\
\text { - The question, also known as the evidence } \\
\text { interrogation part taken by the Prosecutor and } \\
\text { the lawyer, (The Prosecutor presents the } \\
\text { evidence of the accusation, the lawyer presents } \\
\text { the evidence of the offense (also called a } \\
\text { presentation criminal record)). } \\
\text { - The defense, with the procedure of lawyer } \\
\text { calling on witnesses to take the testimony in } \\
\text { turn. Prosecutors and lawyers conduct cross- } \\
\text { questioning and at the same time argue and give } \\
\text { evidence. } \\
\text { - In the final argument, the prosecutor will } \\
\text { submit to the jury the first final argument. Next, } \\
\text { the lawyer will do the same. After that, the } \\
\text { Prosecutor will present the argument to the Jury } \\
\text { for refusal. } \\
\text { - Deliberation and Jury returns a verdict. }\end{array}$ \\
\hline
\end{tabular}

\section{Procedures for litigation in the criminal procedure model of some countries in the world}

The reason for studying litigation procedures of the US, Japan and Vietnam is: The United States is a typical country in the world applying the CP model, has a profound influence on the models of many countries' proceedings around the world. For example, Italy is a testament to the approach to the United States Criminal Model. While Japan applies the $\mathrm{CP}$ litigation model, which is not an interrogation system like in China, Vietnam and many other countries. The historical context has caused Japan to be influenced by the US procedural model, but it is very successful when mixed with the characteristics of the interrogation model. This makes Japanese's litigation procedures unique, creative, and should be consulted. For Vietnam - how has the judicial reform process since 2005 oriented the CP model, with outstanding characteristics, will be clarified in this section?

\section{A. The United States of America}

The United States is a typical country applying CP model of litigation. There, all information obtained during the investigation process has not been considered until it is presented before the trial. Each party will present to the court his "truth", and the judge and the Jury will decide which "facts" are more convincing ${ }^{10}$. Litigation procedures in the United States, including the basic stages, those are,

The testimony section, also known as the "questioning section" is undertaken by the Prosecutor and the attorney. The judge will resolve any legal issues raised by the Prosecutor or defense attorney. However, within the limits of his

\footnotetext{
${ }^{10}$ Ministry of Justice, Topic: Criminal Justice comparison, (Justice Publishing House, Hanoi, 1999), p. 126.
} 
power, the Judge may also ask some questions to clarify the problem with a certain witness called ${ }^{11}$ (The judge barely does this task). In this regard, the study by Stephen Seabrooke \& John Sprack, shown in the "Criminal evidence \& procedure" that, "After opening the speech (if any), the prosecution is called. They are examined in chief by the prosecutor, cross-examined by the defense, re-examined by the prosecutor and then the bench may ask them questions" $^{12}$. Jurors are not entitled to raise any questions during the trial, and allowed only to listen to the testimony and review the evidence. The aforementioned process shows that in the questioning part, the Judge's role is faint, instead it is the role of the Prosecutor and the defense lawyer. That is the most obvious ability to ensure equality for basic functions of CP, (the functions are accusation, defense and trial). Unlike many countries that apply the interrogation model, the Judge is in charge of interrogation at the trial, while the Prosecutor and the lawyer have a fuzzy role. Furthermore, in the United States, the juror is not entitled to questioning. Perhaps this is a regulation to ensure objectivity for the Jury's sentencing function. They cannot be interrogators, and then sentenced.

The right to silence of the accused comes from the legal basis of the United States Constitution ${ }^{13}$, in the 5 th Amendment which ensures that the right to silence, no one is forced to accuse himself. The defendant has the right to refuse to give testimony, or any evidence. Instead, the accused had the right to argue that the Prosecutor did not provide any evidence to conclude the crime. It is also considered the tactic of the accused, if the Prosecutor fails to prove his reasoning, the accused will be acquitted ${ }^{14}$. On the other hand, the accused does not need to answer any questions, unless they decided to give testimony as a witness, they, then, must answer in court. The victim gives the testimony as a witness in the questioning section, if they are summoned by the Prosecutor or a lawyer as a witness ${ }^{15}$. The right to silence is respected and applied in the early stage of the United States judicial history. It is associated with Miranda rules, also known as "Miranda warning", which are well known. It can be seen that litigation procedures in the United States limit State intervention in the trial process. The state prosecutor is authorized by the State to enforce the accusation, but must not affect the basic rights of the accused, in which the right to silence and personal freedom is respected. However, the defect is that the accused can take advantage of the right to be silent to change the testimony in a way that is beneficial to them and obscures the truth, hindering the proof process at the trial. Moreover, the procedure in the United States also focused on finding the truth of the case at the litigation session, not just on the results of the investigation process. This means that the investigation results are not considered before the trial. Thereby, it also demonstrates the neutral role of the Judge. The reason for this is that the State is concerned that the Judge may prescribe accusations during the trial, by interfering with or abusing his power, damaging the rights and interests of the accused and harming the right to defend.

Specifically, the questioning process (also known as the state providing evidence) is as follows: The prosecutor calls the witnesses to the trial and "directly cross examine" (taking testimony). The defense attorney has the right to immediately challenge the prosecutor's question or answer if he believes it violates the Federal Code of Evidence (called FRE), and the Judge will decide on that objection whether to prohibit or allow further questions or answers ${ }^{16}$. Immediately after the prosecutor interrogated, the attorney "cross-questioned" that witness. Usually, attorneys (as well as Prosecutors) can only ask "leading" questions while "cross-questioning". It should be noted that it is possible to isolate witnesses from each other when questioning them. This procedure is quite common in criminal trials in many countries, in order to obtain objectivity in the testimony at the trial, as well as to ensure information confidentiality and personal confidentiality in certain circumstances. However, lawyers may refuse to cross-examine witnesses, so they may lose the opportunity to question the witness. However, the US Criminal Law still allows defense lawyers to resummon the same person in the defense section, but only to directly consulted, and not to be asked the usual questions.

\footnotetext{
${ }^{11}$ Federal Rules of Evidence (Rule 614 (b)), source: http://.uscourts.gov/uscourts/Quy tắcsAndPolicies/quy tắcs/2010\%20Quy tắcs/Evidence.pdf.

${ }^{12}$ Stephen Seabrooke \& John sprack, Criminal evidence \& Procedure, (London: Blackstone Press limited, Reprinted, 2004), p. 261-263.

${ }^{13}$ The US Constitution, source https://.vietnamese.vietnam.usembassy.gov/doc uslegalsystem x.htm.

${ }^{14}$ Phan Van Ba and Phan Xuan Thao, Everyday American Law, (General Publishing House of Ho Chi Minh City, 2012), p.43.

${ }^{15}$ Richard S. Shine, American Criminal Procedure Model, Proceedings of Scientific Conference on "Criminal Procedure Models in Some Countries in the World - Experience for Completing Vietnam's Criminal Procedure Model ", organized by the Vietnam-Europe Justice Partnership Program (JPP) and the Supreme People's Procuracy in Hanoi on 15-16 November 2011.

${ }^{16}$ Richard S. Shine, American Criminal Procedure Model, Proceedings of Scientific Conference on "Criminal Procedure Models in Some Countries in the World - Experience for Completing Vietnam's Criminal Procedure Model ", organized by the Vietnam-Europe Justice Partnership Program (JPP) and the Supreme People's Procuracy in Hanoi on 15-16 November 2011.
} 
Lawyers have the right to ask additional questions to witnesses when "re-cross-questioning," but limit to the issues raised during re-consultation. The prosecutor, after fulfilling the burden of proof, will declare to close the state case. Thus, the antagonistic activity of the parties is continuous, including additional questioning methods, which are very applicable in interrogation sessions. Cross examination and re-cross examination is a unique, timely procedure for litigation, avoiding wasting time and showing the positive role of defense counsel. It also proves that the questioning activity does not have to rely mostly on the documents in the prepared case file, but more importantly the information provided directly by the witness at the trial. This factor is completely opposite to the litigation sessions in the trial following the interrogation CP model. They are called the "case at file". That is, the fact that the case is in the file, right in the pre-trial stage, the crime is clear, the litigation session of the duty to verify the evidence for sentencing.

The cross examination, the attorney calls witnesses to take the testimony in turn. This process of a lawyer may be objected by the Prosecutor and whether or not to allow the objection is within the power of the Judge. It is similar to the Prosecutor's interrogation procedure in the state's testimony. At the same time, the Prosecutor is entitled to cross question witnesses after the counsel has finished. The lawyer now has the opportunity to oppose the Prosecutor's crossexamination, and of course, whether to allow the Prosecutor to continue to ask questions and answers depends on the Judge, under the FRE rule. Next, the attorney has the right to re-direct the witness, and the Prosecutor is re-questioned. Finally, the defense attorney will declare the end of his defense. It was a process of continuous reasoning, which made the dramatic, generalized trial as Robert A. Carp and Ronald Stidham said, that after the defense lawyer returned to his position, the Prosecutor was entitled to give proof of rejection. The lawyer in turn made an appeal to "beat up" the accusation. Then each side gives the final arguments ${ }^{17}$. Thus, the difference in "evidence provision" and "defense" is that the initiative belongs to the Prosecutor and the defense attorneys are significantly different. One side seeks accusatory evidence, the other party seeks evidence of defense. The party which initiates the proceedings is the one entitled to ask to questions and bear the burden of proof, and may be opposed by the other party. The arguments are continuous, and dramatic. There is no separation between the interrogation, response and debate session. We believe that countries that maintain their traditional CP model should absorb this rational element of the litigation system.

In the final argument section("argument process"), the Prosecutor will submit to the Jury the first final argument. Then, the defense counsel will do the same. After that, the Prosecutor will present the argument to the Judge for refusal ${ }^{18}$. If the trial does not have a Jury, the Prosecutor and the lawyer will present their final argument to the Judge alone -the one who decides on the evidence and the applicable law. The final reasoning procedure is quite simple. It can be explained that, after finishing the final argument, the Judge will read his instructions on the applicable rules of law so that the Jury will apply to the facts of the case because the case will be decided by the Jury ${ }^{19}$. The question here is, does the Jury convince the judge to be objective? Don't worry, because the judge has the right to read instructions to the Jury, and the judge has the right to comment or not comment on the evidence while reading the instructions. However, the Judges seldom exercise his review right. Because it can interfere with the function of the Jury, and lead to the possibility of appellate rejection of the ruling and the Court must open a new trial for the case ${ }^{20}$. Thus, in the United States, the Jury has the right to sentence, not the judge. The Jury trial function in the United States has made the distinctive feature of the litigation model in the world, as well as in legal scientific research. Trial procedures in the United States do not expect the Judge to intervene too much in the litigation process, for fear that the Judge abuses his power, interferes with the rights of the accused and detracts from the right to defend.

\section{B. Japan}

The CP Code 1948 of Japan ${ }^{21}$ (partially amended and supplemented in 2004) (2) $^{22}$ shows the characteristic of the litigation CP model, but still interleaves some procedures of the interrogation system. The Law on Criminal Procedure of Japan is close to the United States Criminal Procedure Law, after that it was no longer mainly subject to the CP Code of Germany and France as before $1945^{23}$. Due to historical circumstances, Japan has been subject to the United States intervention in social reform.

\footnotetext{
${ }^{17}$ Robert A. Carp \& Ronald Stidham, Out line of the U.S legal sytems, Congressional Quartly, Inc, year 2001, p. 108- 109, 111, 206- 210, source: http://ufdcimages.uflib.ufl.edu/AA/00/01/16/95/00001/LegalSystem.pdf.

18 Federal CP Rules (Rule 29.1), see http://www.uscourts.gov/uscourts/Quy tắcsAndPolicies/quy tắcs/2010\%20Quy tắcs/Criminal\%20Procedure.pdf

${ }^{19}$ Federal CP Rules (Rule 30(c)).

${ }^{20}$ Federal CP Rules (Rule 30(d)).

${ }^{21}$ Source http://tks.edu.vn/law/cate type/40_1_Luat-nuoc-ngoai.html

${ }^{22}$ Source http://tks.edu.vn/portal/detailtks/5143 66 0 0 MO-HINH-TO-TUNG-HINH-SU-NHAT-BAN.html?TabId=\&pos=

${ }^{23}$ Source http://tks.edu.vn/portal/detailtks/5143_66_0_MO-HINH-TO-TUNG-HINH-SU-NHAT-BAN.html?TabId=\&pos= 40
} 
In the field of criminal justice procedure reform, the Japan Criminal Procedure Model has approached the United States Criminal Procedure Model. In the process of drafting the CP Code in 1948, there was active support from the United States and the new Code clearly reflected the viewpoint of the United States law, specifically in the rules of the principle of litigation, method of collecting and using evidence, limited in accepting indirect evidence ${ }^{24}$. However, the trial procedure in the Japanese CP model has many creative and unique points. That is, (i) the Japanese CP model did not apply a Jury trial as in the United States; (ii) the Judge only plays an arbitration role for the parties to litigate; (iii) in the United States, if the accused pleaded guilty, applying a shortened procedure, the Judge will decide the penalty, while in Japan even if the accused is guilty, the trial is still going on normally on the principle of litigation and then the judge decides the penalty. Thus, the role of Judges in Japan is higher than that of the United States Judges. It is consistent with the trial procedure without Jury in Japan. We find that the participants in the litigation shall have the real equal rights, the Judge only has the role of arbitration. This is one of the characteristics of the CP model of litigation. However, the Judge has the right to sentence and even if the accused pleaded guilty, the Judge still adjudicates, because of the fear that the plea may cover up the truth of the case or neglect the offense. This feature is often found in the interrogation model of CP.

In Japan, the Court only hears the accused's offenses on the basis of the prosecution decision presented in court. The Prosecutor has the right to change, supplement or withdraw the prosecution decision before and during the trial period. The court has the right to adjudicate offenses less than the charges that the Prosecutor Institute has prosecuted. When it is necessary to hear the accused for a more serious offense, the Prosecutor must change the claim, otherwise the Court will postpone the trial to ask the Prosecutor to change the indictment (Article 312 of the Japanese CP Code). Regarding the above mentioned issues, it shows that: (i) in Japan, the changes, additions and withdrawals of prosecution decisions are regulated specifically: at the trial, the amendment and supplementation of the prosecution decisions must not lead to the change of the crime, it can only change the facts, information related to the penalty decision; (ii) if the addition or change of the prosecution argument or the change of the applicable law poses a serious disadvantage to the defendant's defense, the Court may postpone the hearing in a time for the accused to prepare excuses on that additional issue. The procedure for withdrawing the prosecution decision in Japan has a positive meaning, is a good experience, because it guarantees the defense of defendants.

In Japan, the Court is not aware of the case file. The prosecutor transfers the case to the presiding Judge when starting the trial. This procedure is intended to prevent prejudice, which may affect the right of innocent speculation. Before opening the formal trial, the Judge is handed the indictment, and the evidence and documents held by the Prosecutor, selected and presented at the trial. The content of the indictment is very condensed, only the information about the defendant's identity, the crime constituent is prosecuted. Upon receiving the indictment, the Court must immediately send the defendant a copy of the indictment, and immediately inform the defendant the right to have a lawyer and the Court may request the appointment of a lawyer if he or she cannot hire the lawyer himself.

The litigation is started by the Prosecutor announcing the indictment. This procedure is similar to the trial procedure in many countries around the world applying the interrogation system. It proves that the litigation system in Japan intertwines the logical elements of the interrogation CP model. In Japan, it is not permissible for the Prosecutor to disclose the victim's information when disclosing the indictment, in the following cases: (i) The Court is resolving the case that the victim has been harmed, or seriously injured in physical or mental health; (ii) or a representative of the victim demanded to keep the information confidential. This is a unique point that can be consulted, because this procedure is completely different from the laws of many countries in the world and in Vietnam (in Vietnam, the indictment includes comprehensive and detailed information of the case). Its purpose is to protect the right to confidentiality of private life, and the rights personal freedoms, which are widely recognized.

After the Prosecutor read the indictment, the presiding Judge informed the defendant the right to silence during the trial. Next, the defendant and the lawyer presented issues related to the case. This is an opportunity for the accused and defense counsel to present their views on the case, whether the Prosecutor's allegations are true or false. Followed by the defendant's procedure for making a plea of guilty plea, (note that the accused can plead guilty to one or more prosecution arguments in the indictment). After hearing the defendant raise the arguments about the guilty plea, the Prosecutor made his point. The opinion of the Prosecutor is the basis for the accused, the lawyer and the presiding Judge consider and decide to apply the shortened procedure with the point that the accused admits to be guilty and in some simple case (Article 291, Article 291-2 of the CP Code of Japan). Hence, in Japan, after the disclosure of the indictment is an immediate argument, rather than an interrogation separated from the controversial procedure as in the interrogation cases that we often see. It is a good experience, because it avoids the cumbersome problem and the debate will not be boring. In addition, as in the United States, the defendant's admitting-guilty procedure is the basis for the

\footnotetext{
${ }^{24}$ Source http://tks.edu.vn/portal/detailtks/5143_66_0_MO-HINH-TO-TUNG-HINH-SU-NHAT-BAN.html?TabId=\&pos=
} 
next steps of the proceedings. Moreover, in Japan and the United States, all judicial procedures at the trial must not harm the defendant's defense. For that purpose, the procedure for litigation in Japan did not allow subjective imposition from the Prosecutor and the Presiding Judge.

In case the used voluntarily declares, the Presiding Judge has the right to ask questions and ask them to answer necessary issues at any time of the trial process (Clause 2 Article 311 of the CP Code of Japan). This provision provides flexibility for the Presiding Judge to classify whether the accused needs to be questioned. If the accused has voluntarily give testimony, it is not mandatory to interrogate them.

The trial does not allow the participants to question defendants too many questions, in order to avoid interference with the rights of the defendants, especially the right to silence and defense. It is also consistent with the defendant's right to be absent at trial. In particular, the defendant is absent from the trial in many types of crimes they have committed, with a punishment that is not a prison sentence, or a fine for a crime that is not large. Even if the imprisonment penalty is applied, the defendant only needs to be present when sentencing; or in other cases if the defendant's presence is not necessary for the protection of their rights, the Judge may allow the defendant not to be present at the trial. In addition, the Court may also adjudicate the accused in their fault - it is the defendant who has been properly detained but refuses to appear without good cause and makes it difficult for the staff to exercise judicial duty (Article 284, Article 285, Article 286-2 of the CP Code of Japan). Thus, the trial of absenteeism in Japan is quite flexible, substantive, and ensures the basic rights of the accused.

Regarding questioning the harmed procedures: the harmed may present their opinions about resolving the case, state their views on the application of law, check the evidence and question the testimony related to them, raise damages claims, verify evidence, modify accusations, etc. (Article 292 of the Japanese CP Code). The Judge and the Judges in the Trial Panel may ask the victim some questions, which is not mandatorily. Other people involved in the proceedings may also ask the harmed questions but they must seek permission from the Presiding Judge. In this case, the Presiding Judge can cut the question if the content is unsounded or unrelated to the case. At the trial, if the victim has filed a document to prove it, the Presiding Judge must have the responsibility to read out the document aloud to everyone.

Regarding the procedure of questioning the witnesses, examiners and interpreters: According to the provisions of Article 299 of the Japanese CP Code, after informing the Presiding Judge, either the Prosecutor, the defendant or the lawyer has can ask these people, on the principle that the party that requested the evidence first is allowed to ask first. The trial also strictly regulates the witness questioning procedure associated with evidence-checking procedures in the following matters: (i) the right to request information in advanced: Before cross-examining witnesses, one the parties (the accusing, the accused) must provide the name and address of the witness and tell the evidence which support his argument to the other party. This procedure will avoid the Prosecutor's rejection of the evidence presented to the court, because the Prosecutor will explain the reason for not being aware of this evidence; (ii) The Prosecutor directly inspects the evidence provided by the lawyer: At the trial, if the evidence filed by the defendant is not considerable, the Presiding Judge allows the Prosecutor to check right at the trial. If the evidences of the defendant are many, the trial is suspended for the Prosecutor to check them. In contrast, lawyers have the right to collect evidence and study the Prosecutor's records to prepare for the defense. The prosecutor has the right to collect evidence and see attorney's records. Thus, the method of collecting, examining and evaluating evidence at the trial is fair for both the accusing and acccused party.

Conclusion: The interrogation procedure in Japan is quite strict, based on the goal of ensuring human rights of the defendants and related subjects in the case. Despite the application of litigation systems, some litigation procedures are characterized by the interrogation system, which is very reasonable. As becoming the principle of CP legislative act and law enforcement, that all proceedings must not harm the defense rights, and must ensure human rights of the accused and the victims. The judge's interrogation for the defendant, the victim and witnesses is limited, as this responsibility is given to the Prosecutor and the defense counsel. It is worth noting that, despite the public litigation session, the right to confidentiality, the freedom of the victim is guaranteed. The Presiding Judge focuses on controlling the trial, guiding and assisting the parties to provide evidence to prove and exercise the rights prescribed by law.

\section{The Socialist Republic of Vietnam}

In Vietnam, in the period 1945-1975, the model of CP was applied differently in two regions. The North applied the CP model of the Soviet Union (Russian Federation today), the South applied the CP model of France, not according to the US CP model. The Law on Criminal Procedure in 1988, later replaced by the Criminal Procedure Code in 2003, formally shaped the Vietnam Criminal Procedural Law model with the characteristics of the interrogation system. 
As evidence for the above statement, it can be referred to the book "Criminal-Procedure brief lecture" by Nguyen Quoc Hung ${ }^{25}$. The book is presents quite clearly about the litigation procedure in the pre-1975 period in Vietnam - it bears the essence of the interrogation model and is influenced by French law. Because there are court sessions in the forms: Court of Misdemeanor, Court of Persecution and the Court of Felony (based on the nature and consequences of the crime) and the CP at the time assigned a great power to the Judge of the Court in questioning and directing the investigation of judicial police, including additional investigations when the evidence is not clear (pages 32-33, page 76), etc. The Judge held a great power and governed all investigations and trials. However, it is interesting to note that during the pre-trial period, the Judicial Police only questioned the preliminary questions, and the Judge also only questioned but in reserve nature. The interrogation work is more important at the trial ${ }^{26}$. The litigation procedure at that time had the defenders, and prescribed fairly strict rights to private prosecution, including the right to prosecute; prescribing complaints and appeals, the acquittal of innocent defendants in the procedural stages. The above mentioned regulations show that in the interrogation model in Vietnam before 1975, the elements of the litigation system were intertwined. These are significant progressive judicial procedures during this period.

It can be explained that before 1975, the model of CP in Vietnam was different between the Southern and the Northern, which was the consequence of the Vietnam war. In northern Vietnam, it moved forward to socialism, greatly influenced by Soviet law. While in the Southern, the French law still prevailed until before 1975, even though its political regime was influenced by the United States at this time. The dominance of the United States law in the Southern is unstable temporary. Therefore, the French law under the model of interrogation CP is still maintained - which inherently exists with the rule of French colonialism in Southeast Asia, including Vietnam nearly a century.

Today, Vietnam still applies the interrogation model of CP. Since 2005, Vietnam has conducted extensive judicial reform, with the orientation to complete the $\mathrm{CP}$ model by overcoming its limitations and absorbing the logical nucleus of the litigation CP model. The model of Vietnam CP shows basic characteristics, that is,

- Criminal proceedings Vietnam does not consider the case a dispute or a legal conflict between the parties. Because judicial authorities conduct prosecution, investigate the case independent of whether the victim has made a claim or not. The State considers criminal cases are the infringement upon the common interests of the public and the whole society; therefore, the responsibility to settle cases belongs to the will of the State, whose representatives are the Police, the Procuracy and the Court. Only a few simple criminals are dealt dependent of the will of the victim. These factors lead to the fact that the agencies conducting legal proceedings have a great authority, they mainly perform criminal investigation and accusation, while the role of defense counsel is very faint; as well as the accused and the defendant, who are usually put under a passive position, are often imposed with this will.

- The purpose of resolving a criminal case is to consider the truth of the case first. Therefore, the interrogation method becomes the mainstream in the procedural stages. The state makes use of all possible resources to prove and discover the crime. The advantage is that criminals are controlled and hidden crimes are reduced. However, due to the importance of using interrogation method in resolving cases, the situation of abusing of power that harms the rights of the accused still occurs. As the spirit of judicial reform in Vietnam, under the direction of ensuring and protecting human rights and citizenship, the Criminal Code 2015, becoming effective from January 1, 2018, has set new points such as when interrogating the accused, the accused must be recorded or filmed.

- Vietnam Criminal Procedure divides the process of resolving criminal cases into procedural stages. Each stage of proceedings is assigned authority to the Investigation Agency, Procuracy, and Court. These entities closely solve the case, have high professionalism, and coordinate well during the process of resolving the case. Specifically, the Procuracy in Vietnam, with the function of exercising the right to prosecution and to supervise judicial activities, contributes to legal proceedings so that to ensure legislation activities, protect human rights, and guarantee the appropriateness to Vietnam's economic and social conditions.

- In the Vietnam CP model, there is always a case file. The case file is opened by the Police Department, archived and reflected evidence; completed at the stages of the proceedings and held by the Court at the end. Actually this refers to the "case file". That is, the case file reflects, contains evidence, documents, reflecting all proceedings, used for prosecution and litigation at the trial. The inevitable consequence is that the State cares and gives great powers to judicial officials, thus, coincidently, the investigation, prosecution and adjudication agencies are all responsible for proving crimes, including the Court. As an invisibly result, the person who is accused is becoming a counterweight to the judiciary.

\footnotetext{
${ }^{25}$ Nguyen Quoc Hung, Criminal-Procedure brief lecture,Saigon1956

${ }^{26}$ Nowadays, the structure of Vietnamese court is not alike before, but it still remains the nature as an interrogation $\mathrm{CP}$ model.
} 
- Trial procedures at a criminal trial in Vietnam, going through 5 steps, include:

+ Procedure for opening the trial;

+ Litigation procedure (including 2 parts: interrogation procedure and debate procedure);

+ The accused says the last word;

+ Deliberation;

+ Sentencing.

The division of steps in the judicial process shows the prudence in verifying evidence at the trial and where the interrogation takes a leading role, as well as upholds the role of the Court.

- In Vietnam, for the first time, the rules of the innocent speculation and the principle of litigation are established; and more clearly noted the principle that the Court tried in a timely, fair and open manner in the 2013 Constitution. The new criminal Procedure Code has extended certain rights to the accused, including the right to defense. However, the limitations of the CP model in Vietnam have not been effectively overcome, that is,

(i) the basic functions of $\mathrm{CP}$ are not clearly differentiated.

(ii) the principle of innocent speculation and the principle of litigation, though newly regulated by the Law on CP in 2015 , is still formal in both normative and practical aspects.

(iii) there has not yet established and ensured the cross-examination procedures of the parties to the dispute at the hearing, the reason is that the interrogation procedure and the dispute procedure (two separate stages) is called a litigation procedure, are not yet integrated into one, making litigation unfavorable and making the trial lack of attractiveness.

(iv) there has not yet fully complemented the rights of the accused, including the right to silence, the right to legal advice, defense and confidentiality of the private life, personal freedom of the obligee crime, the right to choose a Judge to judge for the defendant (only adjudicated by a judge or trial with a juror); not yet extended the defendant's right to be absent at trial; not yet developed the right to prosecute the case at the request of the victim, so that they have the right to self-decision in many types of misdemeanor crime, less serious crimes, to reduce the burden of professional and procedural costs.

(v) the right to defend in the pre-trial stage is faint, limited; not yet extended defense rights in a substantive way and promoting the autonomy of lawyers.

(vi) the authority to prosecute a case and the authority to submit additional investigation files of the Trial Panel is not consistent with the trial function; as well as the limitation of the trial as the Court is entitled to impose a more serious verdict than the crime prosecuted by the Procuracy, which is inconsistent with the prosecution's role and violates the principle of innocent speculation.

(vii) at the trial, the fact that while the Procuracy withdrew the entire prosecution decision, the Court still adjudged is inappropriate, instead the Trial Council must suspend the case or declare not guilty.

(viii) the assigning the right to interrogate at the trial to the Trial Panel, not the Prosecutor and the lawyer, is inconsistent with the trial function and adversely affects the principle of innocent speculation.

(ix) they allow the Court to hold a case file to prepare for the litigation session, which will inevitably incriminate prejudices and bias actions of the Court during the trial, affecting the principle of innocent speculation, but instead the Court should only have a summary of the case or should only get the indictment.

(x) There is no specific law to protect witnesses, nor to protect competent persons in judicial activities, to help facilitate the settlement of the case. 